\title{
THE FIRST PRINTED TEXT IN THE WORLD, STANDING TALL AND ISOLATED IN EIGHTH-CENTURY JAPAN: HYAKUMANTŌDARANI
}

\author{
BYROBERTG.SEWELL
}

\author{
Robert Sewell is associate university librarian for collection \\ development and management at the Rutgers University Libraries
}

It is undoubtedly true that printing was invented in China. The Chinese developed all the necessary elements required for printing at an early stage. Their writing system was formed more than four thousand years ago. They imprinted images from carved seals well before the birth of Christ. The first paper was produced in China in the first or second century A.D. Rubbed ink impressions were taken from stone inscriptions before the second half of the sixth century in China. In general, their civilization was far more developed than that of any other country in the region; however, there is no physical evidence that the Chinese were the first printers. The first extant specimens of textual printing are found in Japan and Korea, ${ }^{\mathrm{I}}$ dating from the eighth century. The earliest dated, printed texts in China are from the ninth century. ${ }^{2}$ Someday an earlier specimen of Chinese printing may be found that predates those in Japan and Korea. But for now, the Japanese and the Koreans have the claim to the earliest printed texts in the world, and it is quite certain that these texts were created very near the inception of the printed word.

The origin of the printed word in Japan, as well as throughout East Asia, is related to the Chinese writing system and Buddhism. Buddhism was a powerful force in the development of East Asian civilizations, and its texts were written in Chinese. Buddhism was introduced to Japan perhaps as early as the fifth century by Korean monks who brought with them Buddhist texts written in Chinese. By the eighth century, the religion and the writing system had made a deep impression on the Japanese elite, who had no writing system before the introduction of Chinese script. The adoption and adaptation of the Chinese writing system by the Japanese to represent their own language took place over centuries and with great difficulty, given the profound difference between the Chinese and Japanese languages. 


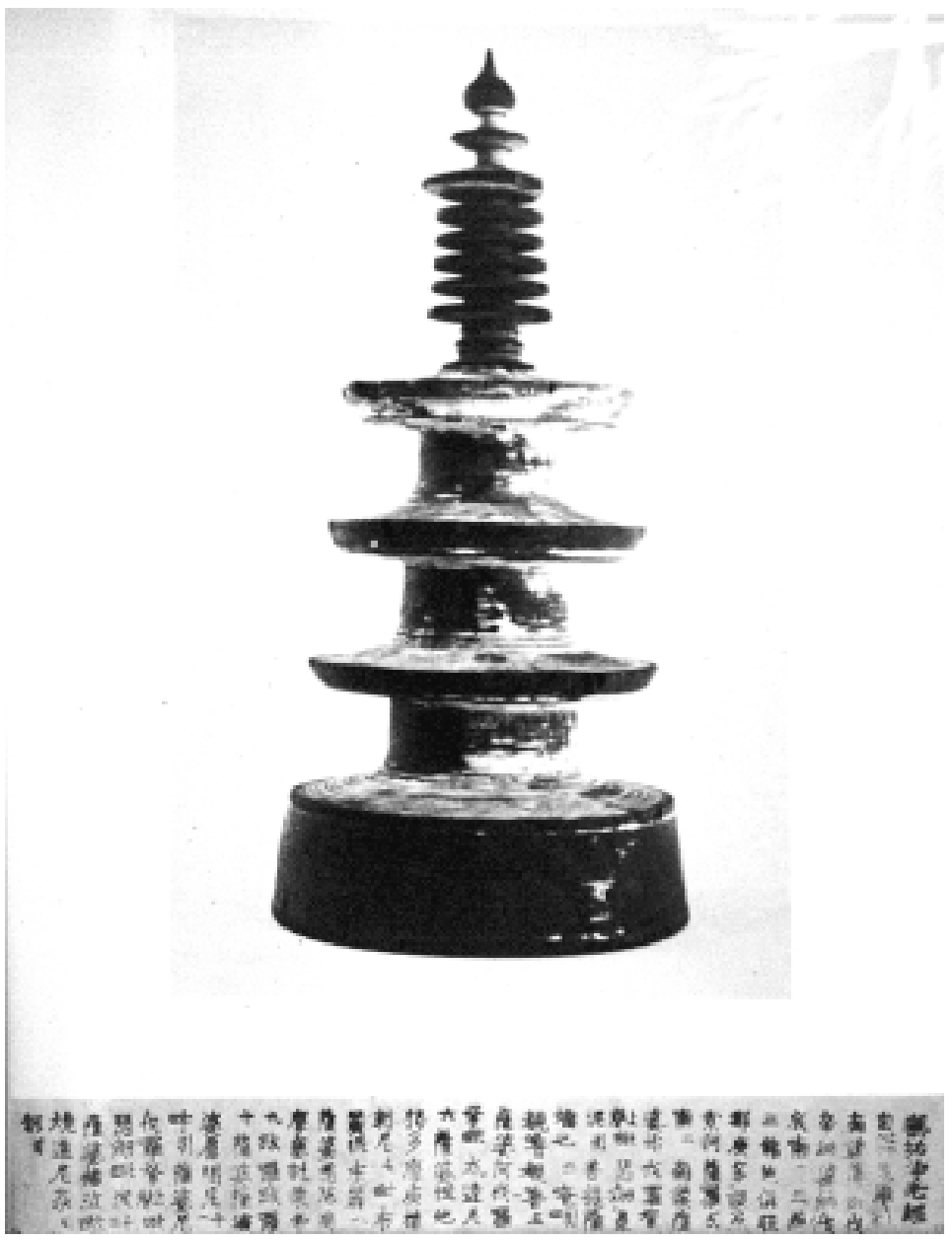

Figure 6.I Typical unit of the Hyakumantō darani, consisting of one darani and pagoda 
In East Asia, Chinese has played a role similar to that of Latin in Europe. Written Chinese was used by scholars, clergy, and for official record keeping for centuries in Japan and Korea. Neither the Japanese nor the Koreans had developed a writing system before they came in contact with Chinese civilization. When they began to represent their own languages in a written form, they used the Chinese writing system, just as the Europeans used Latin or Roman letters to represent their vernacular languages.

There are, however, fundamental differences between the relationship between Latin and European languages on the one hand and those of Chinese and Japanese on the other. Latin and the vernacular languages of Europe are part of the same basic language family. Chinese and Japanese are profoundly different languages. Chinese is of the Sino-Tibetan language family. Japanese is hard to classify, but it is usually identified with the Ural-Altaic language family. The sound systems of the languages are very different: Chinese words are basically monosyllabic and tonal; Japanese words are polysyllabic and have no tones. Chinese has no grammatical inflections to indicate such elements as tense, whereas Japanese is a highly inflected language in which adjectives and verbs are both inflected. Furthermore, the syntax of Japanese is unlike Chinese. The word order of Japanese is basically subject, object, and verb, whereas Chinese is more like English word order with subject, verb, object. From a purely linguistic point of view, I believe the Chinese writing system is inappropriate for representing the Japanese language. In fact, if you had to start from scratch, you could use Chinese characters to represent English with no more difficulty than using Chinese characters for Japanese. The use of Chinese characters in the early Buddhist texts printed in Japan is especially curious as we shall see.

The Japanese texts that represent the earliest authenticated printed texts in the world are part of a set called Hyakumantō darani or One million pagodas and darani. Each unit of this set consists of a miniature pagoda containing one printed Buddhist charm or prayer called dharani in Sanskrit (darani is the Japanese form of this word). These sets were used in Buddhist rituals. Pagodas contain relics of Buddha, and darani are incantations to be used in specific rituals. On a scale rivaling that of modern bestsellers, one million charms were printed on thick paper strips, which were rolled up and inserted into the hollow centers of the wooden pagodas. This project was undertaken between A.D. 764 and 770 by order of Empress Shōtoku. When the work, overseen by $\mathrm{I} 57$ bureaucrats and artisans was completed, one million pagodas 


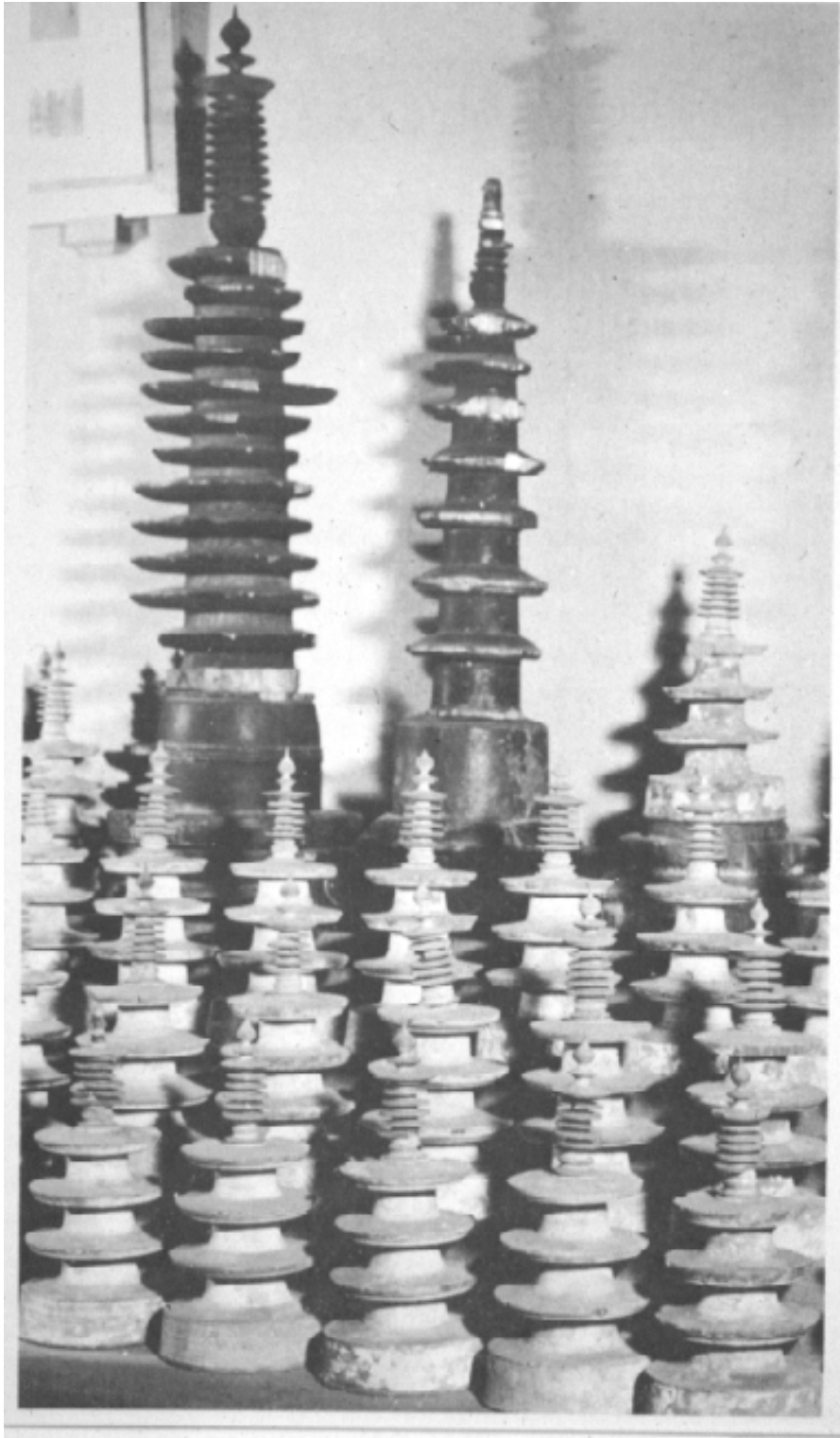

Figure 6.2 Pagodas of various sizes marking different stages in the production of Hyakumantō darani 
were equally divided and distributed among the ten leading Buddhist temples in Japan. Thus, each temple received one hundred thousand units of the Hyakumantō darani. The pagodas were of varying sizes to mark stages in the production: the three-story pagoda was the normal size, the seven-story pagoda marked the ten-thousandth unit, and the thirteenth-story pagoda was for the one-hundred-thousandth unit.

The pagodas were turned on a lathe and made of hinoki wood (Japanese cypress). Each copy of the texts was rolled up and inserted into a hole drilled into the top of the pagoda. The spire of the pagoda, also made with a lathe but from cherry wood, plugged the hole to complete the design of the pagoda and ensure that the roll of printed paper would not fall out. An inventory made in 1908 listed all the remaining pagodas in the one temple where they had survived, Hōryūji in Nara, Japan. There were 43,930 or somewhat less than half of its original allotment, but only 300 were unbroken and complete. ${ }^{3}$

The paper strips on which the darani text were printed were made from strong fibers of mulberry and a variety of hemp, and are thick and durable. The strips are of uniform height $5.45 \mathrm{~cm}$, since they all fit into the same sized holes incised in the pagodas, but vary in width because of the different lengths of the four darani text that were used.

In the same 1908 inventory of the Hyakumantō darani at Hōryūji temple, I,77 I printed texts were listed but by 1937, only one hundred darani remained; the rest, it is assumed, were given away or sold and are now in museums, libraries, and private collections.

There were four texts of the darani (Konpon, Jishin, Sörin, and Rokudo) that were used in the Hyakumantō darani from the Muku Jōkō-kyō sutra. Obviously, the texts were written with Chinese characters, but the text is now unreadable. Chinese characters are generally characterized as graphic symbols for words, comprising a so-called ideographic or logographic writing system. Every character has a phonetic and semantic value attached to it. The characters here, however, are not used this way. They are used in a non-standardized fashion as purely phonetic graphs to represent the four Sanskrit intoned dharani. The Chinese devised this method earlier when translating Sanskrit Buddhist texts that contained these types of Sanskrit incantations. As George Sansom has pointed out, "Since these incantations were regarded as of great power and value, the translators of the Sutras were obliged to find phonetic equivalents for them." Thus, in a sense Chinese characters were used like 
letters of the Roman alphabet, which form words from the sounds of the letters, without regard to meaning of the characters. But there are only twentysix letters in the Roman alphabet, while there are a huge number of Chinese characters. To make things even more confusing, these texts represent the sounds of Sanskrit after passing though China, Korea, and ultimately Japan, with each civilization having distinct languages with very different sound systems.

But in a sense, it did not matter. These particular texts were not meant for reading silently or out loud. These strips of paper were rolled up and inserted into the pagodas, to endure in the darkness of their containers. Why were so many sets made and how were they were produced so early in the evolution of East Asian printing?

The motivations for making such a large number are religious, political, and perhaps romantic. The replication of Buddhist scripture is considered

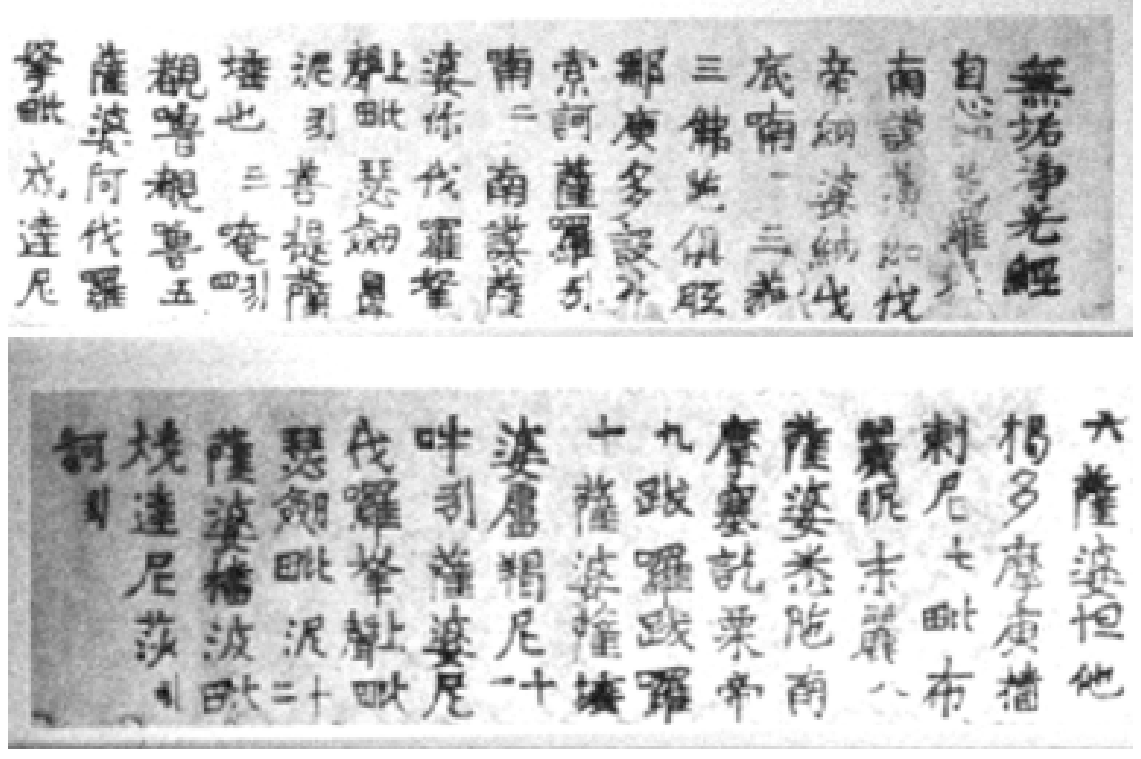

Figure 6.3 Jishin darani text (split into two parts)

meritorious, and certainly one million replications must have been considered especially praiseworthy. The term "hyakuman" literarily means one hundred ten thousands, but in some contexts it can be less specific, meaning something like a myriad. So were there actually one million texts produced? From 
certain Buddhist forms of worship and documentary evidence, it appears that the number one million is correct. For instance, the ritual associated with the Sōrin darani instructs the worshiper to pledge to assemble "I00,000 miniature pagodas, each containing a darani for enshrinement around a central ritual pagoda.... Since Buddhist cosmology postulates the existence of ten directions, each comprising a world with its own Buddha, one million darani pagodas are necessary if the Sōrin ritual is to be properly observed." ${ }^{5}$ This is what Empress Shōtoku literally did by distributing one-hundred thousand of them to each of ten Buddhist temples. ${ }^{6}$ Thus, the production of the Hyakumantō darani can be seen as a pure act of great devotion.

This extraordinary accomplishment was a political statement of power as well. The empress wanted to demonstrate her capacity and power to carry out great projects, and to confirm her forthright conviction that Buddhism and its institutions were the path to a benevolent government, even at the expense of the native religion, Shinto. Even today, we are impressed and a bit awestruck by this massive accomplishment in printing and manufacturing so long ago. There was also a specific historical context that made this statement necessary. She and her cousin Fujiwara Nakamaro were in different political factions in the court during the interim between the empress's two periods of reigning, first under the name of Kōken (749758) and second as Shōtoku. Nakamaro attempted a coup d'état so he could become emperor. Shōtoku's troops defeated and killed Nakamaro, and she reascended to the throne. Within the first year of her second reign, she began her great project, the creation of the Hyakumanto darani.

There is yet another factor that colored the empress's motivations combining political intrigue and sexual scandal which traditional, moralist recorders of history have used to judge her unfavorably. That involves the Buddhist monk Dōkyō. After her first retirement from the throne and the death of a powerful woman in the court with whom she had been allied, the empress was afflicted by what we now term depression. Dōkyō, a Buddhist Master of Healing who served the royal house, was employed to revive her from her state. Their relationship worked on many levels, including, by some accounts, romantically and sexually. Dōkyō, both politically ambitious and anxious to promote the Buddhist faith in court circles, had great influence over the empress during the interim between her reigns and during her second reign. She was behind his rapid rise in court positions, which increased his own power and the position of Buddhism in the court. Toward the end of 
her second reign, she went too far, expressing the wish that he follow her as emperor, even though he was not of royal blood. But court traditionalists and the Shinto establishment prevailed, and Dōkyō was exiled to a remote area where he died. Shōtoku was the last significant empress in Japan, and her legacy has been cast in a negative light by traditional historians.

The debate concerning her legacy that has most consumed modern historians and bibliographic scholars concerns the means of production used to manufacture the $1,000,000$ imprints of the darani. If the four texts were each printed in equal numbers, there would be 250,000 copies of each text. Two theories have been proposed, one holding that the texts were printed using wood blocks, the other contending that they were made from bronze or copper plates. Wood block printing would seem to be more likely, since later printing was almost exclusively produced by wood blocks in Japan as well as the rest of East Asia. There are examples, furthermore, of the sophisticated use of wood block in textile design from the seventh and eighth centuries.

Others have argued that wood blocks would not have been sufficiently durable to produce so many copies. A harder surface such as metal plates would be necessary. Those on this side of the argument point out that Japanese craftsmen, who produced magnificent bronze sculptures during the seventh and eighth centuries, had the skill to produce metal plates.

It is speculated that the metal plates could have been made by two processes. The first postulates that the text was written on thin paper and was pasted facedown on a block of cherry wood, which was then engraved through the paper. The excess paper was washed off the block, which was then pressed into a matrix of clay. The clay was baked, and the plates were cast from the clay matrix with molten bronze. The other possible means of casting the plates is the cire-perdue, or "lost wax," technique, using beeswax instead of wood blocks to make an impression of the texts into the clay mold. Molten metal displaces the wax and bakes the clay matrix, which can then be used numerous times to cast metal plates. Considering the volume of imprints that were made (the durability issue), it seems the metal plate theory must have been the process employed, despite there being no other example of printing from metal plates in Japan until the sixteenth century.

The printing of the texts for the Hyakumanto darani in the late eighth century is a monumental but isolated development in the history of Japanese printing. There is no other mention of printing in historical records until 
the latter half of the tenth century, and no extant example of dated printed texts until the end of the eleventh century. With such an impressive start, why did it stop?

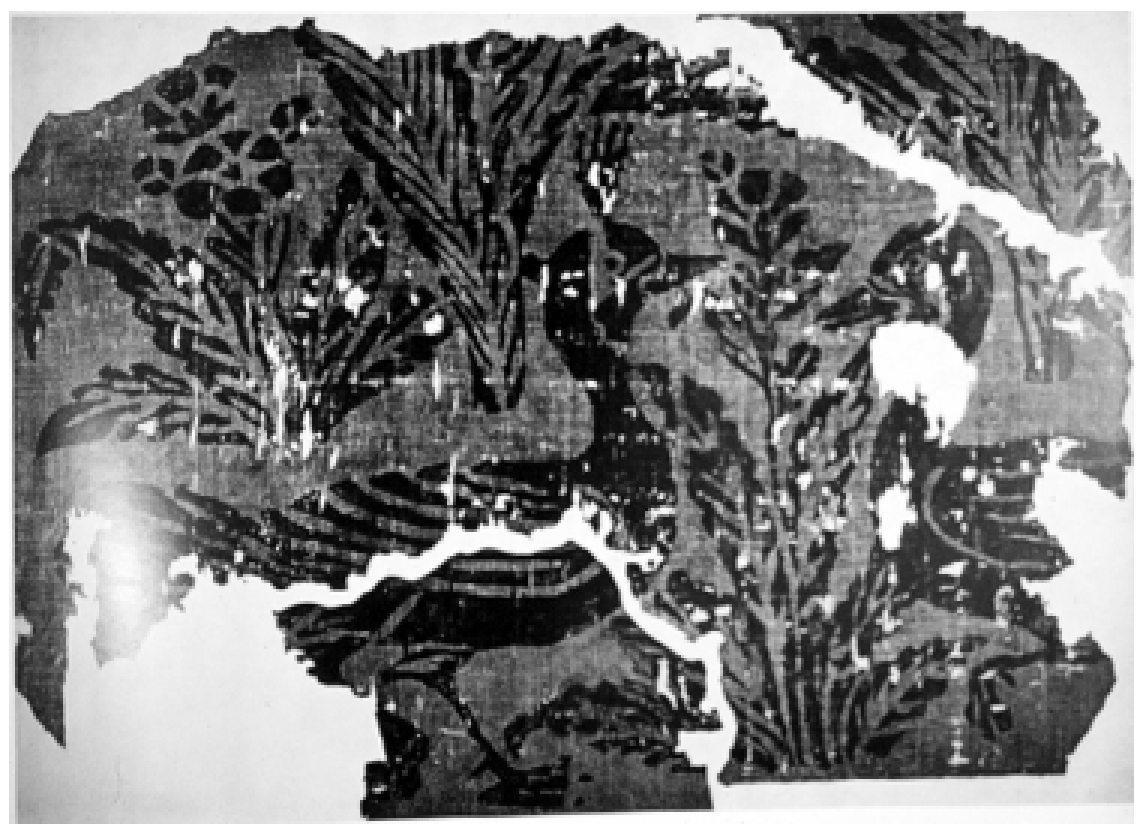

Figure 6.4 An example of printing from a wood block (2I by 48”) on cloth, with patterns of birds and flowers that predates the Hyakumanto darani, indicating Japanese craftsmen had the skills need to create wood blocks for printing the darani

The writing and circulation of texts did flourish during the period when printing seems to have died out. In fact, a rich literary culture flourished from the eighth through the twelfth century during the Nara (645-794) and Heian (794-I I85) periods. It was carried out, however, in the preferred manuscript form. Several reasons for the neglect of printing and the emphasis on handwriting and calligraphy in Japan during this period have been suggested. First, there was little practical need for printing numerous copies of a work, since only a small circle of people was literate-the courtiers and the clergy. Second, handwriting was highly valued by the Japanese, with the art of calligraphy exalted as a major art form.

This magnificent creation in the book arts from eighth-century Japan, the Hyakumanto darani, gives us the first authenticated printed texts in the 


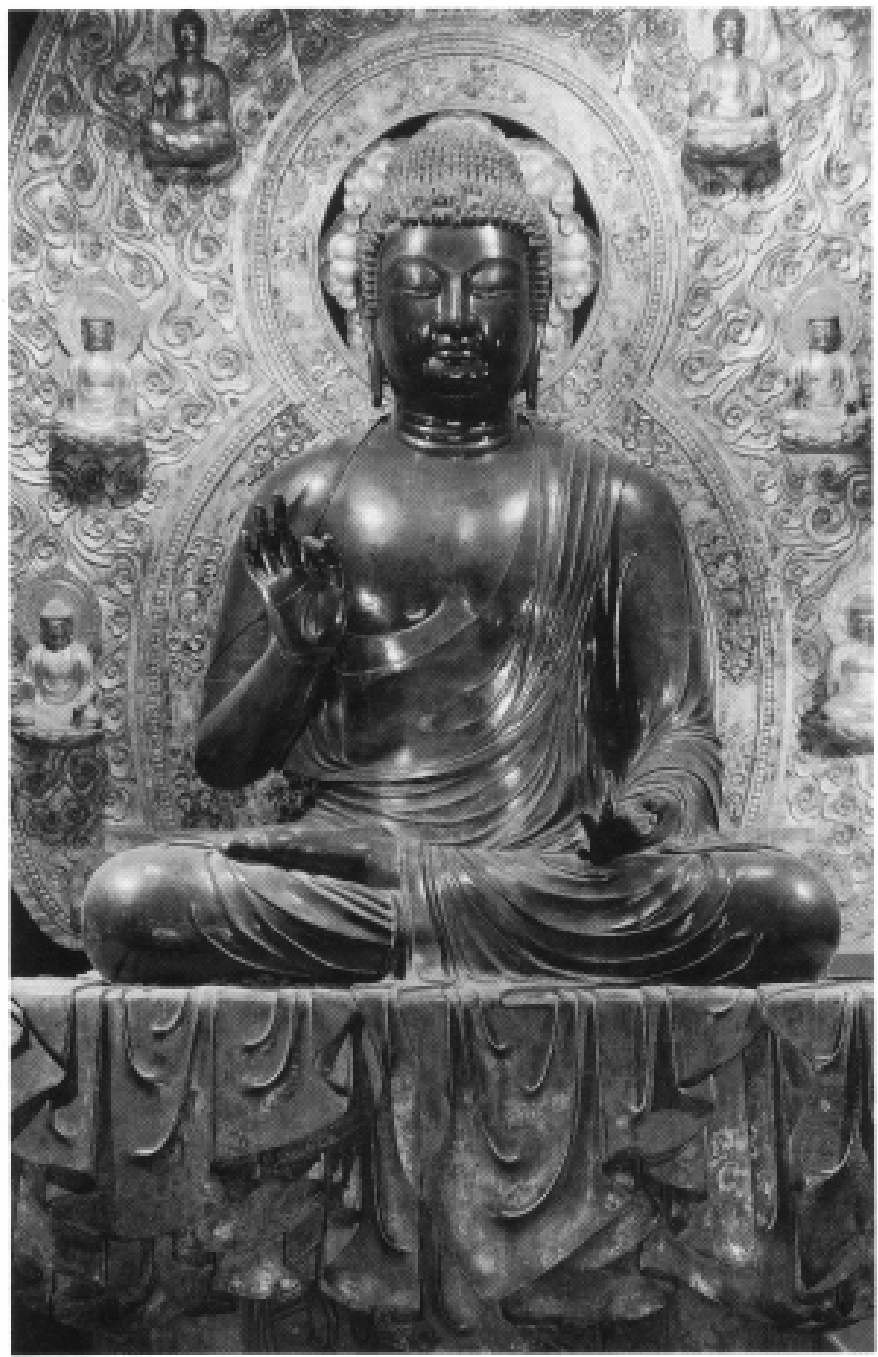

Figure 6.5 Buddhist sculpture cast in bronze in the late seventh or early eighth century, indicating Japanese craftsmen had the skills needed to create metal plates for printing the darani. (The sculpture is of Yakushi Buddha and is located in the Yakushi Temple in Nara.)

world. Their contents are mysteriously lost to us, and were never really meant for us to read. The elegant containers of lathe-turned pagodas kept the texts in darkness. But the gesture and the accomplishment make us glow within. 
Notes

I There is a single example of the Korean dharani, found in 1966 in the Pulguksa Temple in Kyŏngju, Korea. It is thought to have been produced before 75I, from construction records of the Pulguksa Temple and related objects in storage at the temple from a similar period. There is no specific documentary evidence of the existence of the dharani, which is not dated.

2 The earliest printed text from China discovered so far is from the cache of treasures from the great Dunhuang Cave excavation conducted by the archaeologist Sir Marc Stein in 1908. This printed edition of the Diamond Sutra, a Chinese translation of the Sanskrit Buddhist text, is considered to be the earliest "dated printed book." The colophon gives the date as A.D. 868. The Diamond Sutra book, containing text and illustrations, was made from wood blocks and bespeaks of a well-developed printing culture in China.

3 Brian Hickman, "A Note on the Hyakumantō Dharani," Monumenta Nipponica 30, I (Spring 1975): 89.

4 George Sansom, An Historical Grammar of Japanese (Oxford: Oxford University Press, 1960), p. 12. This work begins with a discussion of the introduction of writing in Japan and details the difficulties of adapting the Chinese script to represent the Japanese language. A recent dissertation gives a more exhaustive treatment of the very early evolution of a writing system in Japan: David Barnett Lurie, "The Origins of Writing in Early Japan: from the Ist to the 8th Century C.E.” (Columbia, Diss., 200I).

5 Mimi Hall Yiengpruksawan, "One Millionth of a Buddha: The Hyakumantō Darani in the Scheide Library," The Princeton University Library Chronicle, 48 (I98687): 232.

6 The temples were, according to the historical record, Tōdaiji, Daianji, Gangōji, Yasushiji, Kōfukuji, Hōryūji, Saidaiji, Gufukuji, Shitennōji, and Sãfukuji.

A Bibliographic Note

Not much is available in English on the Hyakumanto darani. Two important articles devoted solely to the Hyakumantō darani include Brian Hickman, "A Note on the Hyakumantō Dharani," Monumenta Nipponica 30, I (Spring, 1975): 87-93 and Mimi Hall Yiengpruksawan, "One Millionth of a Buddha: The Hyakumantō Darani in the Scheide Library," The Princeton University Library Chronicle 48 (I986-87): 224-238. Robert G. Sewell, "The Oldest Printed Text: Hyakumantō darani," Non Solus: A Publication of the University of Illinois Library Friends at Urbana-Champaign 3 (1976): 84-85, represents the author's first reflections on the Hyakumanto darani. When I worked at the University of Illinois at Urbana-Champaign Libraries, it was my 
good fortune to discover in the library's Rare Book Room an unprocessed collection of Japanese rare books and manuscripts purchased from the Japanese literary scholar Joseph Yamagiwa. Among the items was a Hyakumantō darani in excellent condition. The paper was still rolled up within the pagoda. It was quite a thrill to actually handle the twelfth-century old paper and pagoda.

Works that mention the Hyakumantō darani include Robert G. Sewell, "Japanese Printing," in Encyclopedia of Library and Information Science, v. 24, edited by Allen Kent, Harold Lancour, and Jay E. Daily (New York: Marcel Dekker, 1978), 87-95; "Printing, premodern," in Kodansha's Encyclopedia of Japan (1983), v. 6, pp. 246-247; Teien Tsuen-hsuin, Paper and Printing in Joseph Needham, ed. Science and Civilization in China (Cambridge: Cambridge University Press, I985), v. 5, pt. I, pp. I50-5I, 336-37; and Peter Kornicki, The Book in Japan: A Cultural History from the Beginnings to the Nineteenth Century (Leiden: Brill, 1998), pp. II2-I7. Kornicki notes in this book that he is working on an in-depth study of Hyakumantō darani.

Major works on the history of printing and bibliography written in Japanese that treat the Hyakumantō darani include Kawase Kazuma, Kokatsujiban no kenkyū (a study of early typographical editions in Japan), Antiquarian Booksellers Association of Japan, Tokyo 1967) 3 vols.; Kimaya Yasuhiko, Nihon koinsatsu bunkashi [A cultural history of old Japanese printing], Fuzambo: Tokyo, 1965; and Shōji Sensui, Insatsu Bunkashi [A cultural history of printing], (Tokyo: Insatsu Gakkai Shuppan: 1974.) 